Ivan Biliarsky (Sofia)

\title{
Marriage And Power (Images of Authority)
}

\author{
To the memory \\ of Constantinos G. Pitsakis \\ and of Theodore Piperkov*
}

\begin{abstract}
$\mathrm{T}$ he ritual is in the core of my study and it is to state from the beginning that it should be perceived as a combination of text and image that creates a complex of actions having important consequences in different spheres. This article is part of a larger research on the conceptualization of power and its religious basis in premodern societies, carried out through a study of the inauguration rituals that mark not only the instigation of the power of the ruler but also suggests its religious basis, conceptualization and justification. It is grounded on source material from Byzantium and its legacy in the countries of South-Eastern Europe and the Eastern Mediterranean. There is an obvious relation between nuptial church office and royal coronation in Eastern Christianity that has not been entirely studied. In many languages (Greek, Latin, Slavic and so forth) even the appellations of both ecclesiastical rites are the same or similar. Expectedly, the ritual acts correspond too. All this should signify that their meaning is analogous. I strongly believe that they should be studied comparatively.
\end{abstract}

\section{Legitimation of power in pre-modern societies}

The woman - mother, sister, and wife - is one of the main legitimating figures for religiously justified power. This happened in different ways and I shall try to present one of them, namely matrimony. Before embarking on the topic itself, I would like to make some specifications and clarifications:

a) I shall not dare to give an exact definition of power as a phenomenon and as a concept, but we shall attempt some elucidations of it from the beginning. David Cannadine wrote that Power is like the wind: we cannot see it, but we feel its force ${ }^{1}$.

\footnotetext{
* They are two friends of mine that I (or better to say we) lost last years. They, both of them, were very interested - even in different ways - in marriage in Roman and in Christian culture. The influence of Professor Pitsakis on my research is quite obvious in this article. I pray God be ever with them.

${ }^{1}$ D. Cannadine, Introduction: divine rites of kings, [in:] Rituals of Royalty. Power and Ceremonial in Traditional Societies, ed. IDEM, S. PrICE, Cambridge 1987, p. 1.
} 
There are several types of power (social, political, economic and so forth) and it can be exercised in different ways, through different mechanisms, institutions, practices, interpretations and so on, but - in order to simplify the answer only for my needs concerning this my article - I shall dare to define power as a process of imposing the will of one person on another one. This imposition has different forms and it could be (and I would say that in most cases it is) not at all brutal and violent. Even in these soft cases, however, power has to be argued and accepted. The argumentation could be accomplished by force, but order imposed by force usually is not secure and may be accepted only temporarily and in restrictive conditions. Power should be welcomed by the people and this requires a strong legitimation. Without going into detail, I will state that in pre-modern societies this legitimation should be and could be only religious or quasi-religious. The religious interpretation of power resides in its delivery in the hands of an extra-human or divine person, who exercises the authority either through his/her emanation and incarnation as a human or through the delegation of power. Every power aims at the creation and maintenance of order in the society, and the theological argumentation of this order cannot but be related to universal cosmic harmony that is actually the transcendental divine harmony, emanating in our world through power ${ }^{2}$. Exactly this actualization of divine power in the world is, in my view, the legitimation of power in pre-modern pagan societies where the King had the power and was the legitimate ruler because divine presence was channeled through him as the incarnation of the deity or of the sacred in general. In the monotheistic Abrahamic religions, power belongs to God and His terrestrial lieutenant could not be deified. He had his legitimation by the obtaining of Divine grace; thus he becomes the chosen and sacred (meaning: passed through God's anointment) King and ruler. The aim is the same - the achievement of order and harmony in the terrestrial world that come from the divine celestial order - but it comes not as core principle but as Providence and the Will of God. So, the legitimation should be seen as proof of veracity of the Chosenness and of the fidelity of the King to God.

b) The legitimacy of every power should be proved and confirmed continuously during the time of its exercising, but this legitimation and confirmation are especially important in the moment of its formation, of its beginning. Questions of the sort, Why exactly this power? and Why exactly these persons in power?, exist and they should be answered as early as the moment of the investiture of the ruler. In response to the previous clarifications, one can easily answer: the power is in the hands of this person because all power belongs to God or to the deity who maintains universal harmony and homeostasis, and this person is his/her emanation (in the pagan case) or His chosen and His lieutenant. This general answer, however, does not explain how to identify the person who is the emanation of the deity

\footnotetext{
${ }^{2}$ M. Herbert, Goddess and King: The Sacred Marriage in Early Ireland, [in:] Women and Sovereignty, ed. L.O. Fradenburg, Edinburgh 1992 [= C.YTCS, 7], p. 265-267.
} 
or the one chosen by God. To arrive to this elucidation is more complicated. Traditionally, royalty is associated with heritage, and the power is reserved for a single family or a clan. Election of the ruler exists, but in the popular view it is not very typical. Regardless of this opinion, it is to be noted that in pre-modern times election and not inheritance was the usual and somehow more traditional - at least theoretically ${ }^{3}$ - manner by which to select the ruler. This election has however very little to do with our understanding about of elections today. Principally, it was the same: the actual (at least theoretically) bearer of power chooses the person in function. This is the Sovereign - Lord God, a pagan deity or the so-called people of our time. This choice was how transcendental power became immanent - but how accomplish the emanation of the One in the visible world or personalize the lieutenant? The particular ways for accomplishing this are many and could take different forms, the use of a special electoral corpus included. This would be - however - not an expression of its own decision but rather that of the transcendental divine Sovereign.

c) We can say that such an election is a ritual because the transcendental Will can reach us only in a ritual way (or through a prophet). It is followed by a ritual of investiture that confirms and proves it. Thus, we can say that this election is a type of rite de passage in the sense of Arnold van Gennep ${ }^{4}$, during which the chosen person takes on a new quality. This new quality could be either an effect of substantial change, a result of alteration in the person of the ruler (closeness, emanation, divine incarnation etc.), or a change in the relations of the ruler, in his role in the social context; these new relations are actually the new quality. Both of these changes happen through the election - an actualization of the divine will in the visible world.

Some years ago a special article was dedicated to these two types of rite de passage in the case of certain sacraments and ruler's inauguration rites ${ }^{5}$. The text sought to study two pairs of rites with some relation to power: the first (Holy Baptism and royal anointment) changing the person substantially, and the second (marriage and coronation) changing the relations of the person. In my present article, I shall not deal with the first case (that of substantial alteration of the person), not because it is not important, nor because it is not related to the legitimating figure of the woman. On the contrary, in as much as the royal anointment is just such an act, I strongly believe that the substantial change after the rite de passage has a special importance in the investiture ritual as a demonstration of God's choice. Even the usual term for designating the chosen king is anointed. Birth - as the same

\footnotetext{
${ }^{3}$ It is to be emphasized, however, that usually the official solemn act of election was used to conceal the retaining of the power in the family.

${ }^{4}$ A. van Gennep, Les rites de passage, Paris 1909.

${ }^{5}$ I. Biliarsky, Deux ensembles de rites de passage concernant la personne et la 'Res publica': Baptême/Onction et Mariage/Couronnement, [in:] Personne et Res PubliCa, éd. J. Bouineau, Paris 2008, p. 239-253.
} 
type of relevant fact - is directly related to the woman as legitimating figure. Birth has a special relevance because it seems to be in contradiction with divine choice. At least theoretically, no political system was founded on birth, as it is a natural fact, tributary to the fortuitous forces of chance and not to the Wisdom of the Creator. In order to avoid this, however, birth is conceived not as a physical act of heredity, but as a choice made for a clan or family/dynasty. Even more, the very person of the ruler is chosen, but the determination is made in his mother's womb. This is again a scriptural model, based on a quotation from the Book of the Prophet Isaiah: Listen, $O$ isles, unto me; and hearken, ye people, from far; The LORD hath called me from the womb; from the bowels of my mother hath he made mention of my name (Isa 49, 1). Of course, the prophets as well as the biblical patriarchs are used as royal paradigm, and this election certainly is in vigour for the kings too. One should stress, however, that the Holy Scripture uses the expression that the choice of the leader or of the powerful person is done from his mother's womb and not from his father's loins. This confirms the importance of the figure of the woman/mother in the legitimation of authority by birth: not by the natural act but by divine choice from the womb of the mother.

In any chance, just this type of legitimation is not subject of my article and I shall pass to the next part on my study.

\section{Relation and unity as legitimation of power in the framework of universal harmony (or, to simplify the expression: in a pagan culture)}

In my research, I will approach power as a relation. This is not only a type of subordination or a construction of a hierarchy, but a relation of unity, in which the society reaches toward universal harmony - the task, duty and obligation of every power. In this sense, power becomes similar to the Creator in the cosmogonical myth, which tells of the harmonization of the chaos, by which order is inserted into it and thus power is obtained in the universe in order to recreate and sustain homeostasis, life in the world. Power is conceived therefore as a result of the Creation, an imitation of the Creation, and necessary for recreation or renewal of the results of the Creation.

Thus, the relations god-world and king-kingdom could be conceived as a type of unity. They are different, because only different objects can unify with one another. The usual image (or one usual image) of unity in society is matrimony, which is linked to origin and to ancestry, and therefore to the descendent line that it recreates but also to the world by the recreation of the links of society. Marriage is considered in the pre-modern societies as a model of relation, connection and unity. This type of connectivity - modeled after its divine archetype (god-world) - could be a pattern for relation in the political domain. Thus we arrive at marriage, and especially holy marriage, as a legitimation of power in some historical societies. 
The hierogamy is one of the typical means for the legitimation of power in the pagan religions. It has different manifestations in special rituals, is perceived differently in diverse cultures, and becomes the central institution of sacral kingship. It consists of marriage and sexual intercourse between the ruler and a female chthonic deity, usually related to fertility and hunting, or intercourse directly with the goddess of Sovereignty. This rite could take place annually or during the enthroning of a new ruler.

The rituals are well described in the historical and anthropological literature, mostly in Ireland and the Celtic countries in the West, ${ }^{6}$ as well as in some primitive cultures in Asia and Africa. We have an account of the rite of hierogamy of the Irish kings, given by the $13^{\text {th }}$ century author from Wales, Giraldus Cambrensis (Topographia, III, 25). It concerns a practice in Kenelcunnil, Ulster, Ireland. It includes the copulation of the King with a white mare, who serves as the incarnation of the female deity, sacrifice and consumption of the animal, as well as a bath in the broth obtained by boiling her flesh ${ }^{7}$. We see a description that at least partially was designated to horrify the Christian readers. We have to bear this fact in mind, but it does not mean that we should reject the source or neglect the author. It is certain that we see a ritual that could be interpreted as a rite of unification between the ruler and a female deity. Not only does the copulation of the king with the mare support this understanding, but also the subsequent killing of the animal, her boiling, consumption and the king's bathing in the broth. In the context of the Insular Celtic culture, it is easy to discover in this ritual a hierogamy. In result of it, the ruler obtains his power and becomes part of the cosmic harmony through unification with the deity by her incarnation, the mare. For our study, it is important to stress that the unification ritual is presented as gamos, as matrimony, conceived as the supreme form of unity.

In the Irish tradition we have some other examples of matrimony presented as the source of power. These are the so-called Loathly Lady stories found in the $11^{\text {th }}$ century Irish saga, Adventures of the Sons of Eochaid Mugmedon (or Echtra mac $n E c h a c h$ Muimedóin) ${ }^{8}$, as well as in Geoffrey Chaucer's The Wife of Bath's Tale,

\footnotetext{
${ }^{6}$ M. Herbert, Goddess and King..., p. 264-275 and the cited literature.

${ }^{7}$ Giraldus Cambrensis, The Topography of Ireland, trans. Th. Forester, ed. Th. Wright, Cambridge-Ontario 2000, p. 78:

Once all the people had been assembled together, a white mare was led in the middle of the crowd. Then, in full view of everybody, this person of highest rank [the king] approached the mare bestially, not like a prince but like a wild beast, not like a king but like an outlaw, and behaved just like an animal, without shame or prudence. Immediately afterwards the mare was killed, carved up into pieces and thrown in boiling water. A bath was prepared for the king with the broth, and he sat in it while scarps of the meat were brought for him to eat and to share with the people around him. He was also washed with the broth and drank it, not with a cup or his hands, but directly with his mouth. Once this ritual had been performed, his rule and authority were assured.

${ }^{8}$ Adventures of the Sons of Eochaid Mugmedon, [in:] Ancient Irish Tales, ed. T.P. Cross, C.H. SLover, London 1936, p. 508-513; M. Herbert, Goddess and King..., p. 270sqq.
} 
which is a part of the Canterbury Tales. We would like to emphasize the first one, which tells us that after the kiss of Niall Noígíallach (Niall of the Nine Hostages, Eochaid's son), the Loathly Lady became a beautiful maiden, an incarnation of the Sovereignty of Ireland that the prince obtained for himself and his family for many generations.

So, in order to obtain, to possess and to justify his power, the ruler must achieve unity with a superhuman person, and this unity usually takes the form of matrimony or gamos (in order to stress all the aspects of the relation, sexual contact especially). The idea is to represent, to stress the unity-giving power or the powergiving unity, which thus introduces the harmony and order so necessary and inescapable for the very existence of the Cosmos. From the religious point of view, this practice could be qualified as pagan or pantheistic by definition because it appeals not to the Will of the Almighty or to imitation of His actions, but exactly to the harmonization of natural forces, identified with pantheistic gods and goddesses.

\section{Matrimony and power in Christianity}

In Christianity, marriage is also a rite de passage of relation, but it is conceptualized in a different way. It gives the opportunity to pass from a status of relation (absence of relation) to another (presence of relation), which is a paradigm and pattern for some other links. The archetype is the divine model of relation that refers not to human connection but to that of the Lord God. We saw that we find a similar situation in pantheistic milieus, but there the relation or intercourse is physical, whereas in monotheistic religion it cannot but be an imitation of God.

In Christianity, matrimony is a replica of the relation between Lord Jesus Christ, called the Bridegroom, and the Holy Church, called the Bride. This is a relation of unity (as the Church is the Body of Christ) and a relation of power (as God is head of the Church and celestial King). Thus, unity and power enter a complex that will be the focus of our interest. In all the monotheistic religions (and I would say with the People of Israel and in Islam even more than in Christianity), all power belongs to God, derives from God and is exercised by God Himself directly or through His chosen anointed lieutenant. The King is that lieutenant, and all his actions and especially his enthronement should refer to God and should stress the divine origin of his power. So the unity between the Bride-Church with her celestial Bridegroom and King should be the point of reference not only for every wedding but for every act of acquiring of power as well.

The parallelism of the intended result produces the parallelism and similarity between the initiating rites de passage, in our case the royal coronation as a part of the rite of royal investiture, and Christian marriage. It is almost complete regarding the liturgical texts and liturgical actions, and in certain languages even the appellation of the rites is the same: venchanie in Slavic languages or stephano-

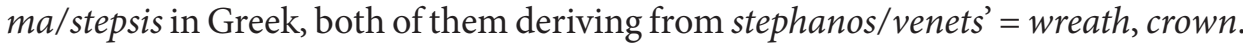


The Greek service is called Akolouthia tou stephanomatos and, in Latin, Officium coronationis nuptiarum. Nevertheless, the concrete historical development of both ecclesiastical offices is quite different. Their practice is diverse: one is widespread and applicable to everyone, having strictly personal legal effects, whereas the other is attached and limited to royalty, with clearly political and religious effects. So, the mentioned parallelism should be seen as deriving not the legal and political (or public) consequences of the rites, but from their identical conceptualization as generative of relations. We see them therefore as rites de passage concerning relation/connection and consequently - power. Despite the different liturgical character and public/legal effects of both rites, they possess many common features and encompass many similar or identical ritual actions, the complex of which should testify to their common meaning and final goals. This imposing deduction forces us to try to demonstrate and make clear this common sense. This means to find out the power-related features of marriage and the matrimonial features of the ruler's power in the relation King-Kingdom.

\section{The rituals and their character}

Both rites - coronation and marriage - had no place amongst the liturgical practice of the Early Church. Imperial investiture followed a military Roman ritual, and early Christian marriage was completely under the rule of the Roman law. To both of them could be added a religious blessing that was only a benediction of the newly created relation without any constitutive implication. Concerning matrimony, these were the so-called Eucharistic nuptials - a special nuptial office with a short Eucharistic liturgy (a kind of presanctified one). After its final establishment as an ecclesiastical rite, the special nuptial office, with no relation to the Eucharist, became necessary for the creation of a matrimonial relation. This happened in Byzantium definitively in the beginning of $10^{\text {th }}$ century in relation to the controversy concerning the $4^{\text {th }}$ wife of Emperor Leo the Wise (by Novella 89 of the same emperor); Church marriage was absolutely necessary for Christians and it became the unique way to create a married family.

The main difference, however, between two rites is in their liturgical character. The Christian nuptial service is a sacrament in all Eastern Churches, as in the Roman Catholic Church, but the coronation never had a place amongst the official sacraments. From the juridical point of view, the sacrament is a strictly normative action, under the rule of the canon law, which should take place in this world but have its results in the celestial transcendental world. This is an act that gives divine grace, which we cannot obtain except from the Almighty. Actually, the sacrament is an act of God, performed in Heaven, to which correspond certain acts in the immanent world fulfilled by authorized persons after the divine will, announced to us by the Revelation. So, the Church presents the institutional way, necessary for the legal relevance of the sacraments and their application in social relations. On 
the other hand, the royal/imperial coronation never took on the character of a sacrament and remained restricted to the moral and ideological sphere. Its moral importance was constantly increasing and had a strong impact on the legitimation of king's power, but it never became a sacrament of the Church and necessary as starting point for power, seen in the optic of the public law.

The Orthodox Church and the Eastern non-Chalcedonian churches always recognized the sacramental character of matrimony. The Roman Catholic Church arrived definitely to the same point some later, during the debate with the reformed theologians. The final decision was formulated at the Council of Trent in order to oppose Martin Luther and Jean Calvin, who both rejected every idea of matrimony's sacramental character. Christian marriage is, they asserted, a pious but secular affair, being under the rule of imperial constitutions and anyway not a sacrament. In response, the Roman Catholic Church created a special canon of the Council in Trent ${ }^{9}$ declaring marriage one of seven sacraments that distribute divine grace, being inaugurated by Lord Jesus Christ as a part of the Evangelical Law. This was the normative culmination of a long tradition of the Roman Church from Late Antiquity onward.

As a sacrament, Christian marriage is an act of God performed through a priest and the participants themselves. That is why the Roman legal concept of divorce is unacceptable for the Canon Law. Once completed as an action in this world, the rite engenders the participation of God and becomes His affair and is thus beyond human control. In order to induce it, the ritual should complete certain acts that are constitutive in their effect. Thus we see that Christian marriage is a rite de passage concerning a transition from one type of relation (or absence of such) to another, or its creation; in our case two persons become one unity, a couple, in their relation to God and then to human society.

Christian matrimony has its foundation in the Holy Scripture, inasmuch as it - like all other sacraments - was founded by Lord Jesus Christ. His first miracle took place at the nuptials of Cana of Galilee (Io 2, 1-11), but actually it has its source in the Old Testament's account of the Creation and especially the creation of the woman from Adam's rib (Gn 2, 21sqq). The true model of Christian matrimony, however, is not the relation between Adam and Eve but that of Lord Jesus Christ and His Church. That is why its main scriptural basis is the Epistle of St Paul to Ephesians $(5,22-32)$, in which the relation between husband and wife is directly related to that of Lord God and His Church. This is, to be sure, the imperative model of Christian matrimonial relation, which also prescribes its beginning and all of its elements. Being at the heart of the theological conception of matrimony, this model of relations has an impact on the liturgical demonstration and

\footnotetext{
${ }^{9}$ Concil. Trident., canon I, Sess. XXIV, [in:] CONCILIUM TRIDENTINUM. Canones et Decreta, 1545-1563, p. 96 - http://www.documentacatholicaomnia.eu/04z/z_1545-1563_Concilium_Tridentinum_Canones_et_Decreta_\%28Altera_Lectio\%29_LT.pdf.html [29 X 2015].
} 
completion of the abovementioned point. It imposes the sacramental character of the ritual, stipulates its religious, social and juridical consequences and relates it to other rites. Here, we have to seek the common model between coronation and matrimony, but we must clarify this model, because the relation of Lord Jesus Christ to the Church is quite complex. The Universal Church is the body of the Saviour and $\mathrm{He}$ is the Head of the Church, being simultaneously King and Priest in the order of Melchisedek.

Coronation was never a sacrament, but it obviously is a rite de passage that joins the Res Publica (the State) and its ruler by creating between them a relation quite similar to the matrimonial one. A comparative study of both rites shows that not only the appellations of the offices identical, but so are some actions, symbols, and liturgical objects, as well. All of them stress the indissoluble relation between the bride and bridegroom, and therefore between the king and the kingdom as well.

\section{The Crown}

As we have already pointed out, the names of both rites come from an object that is usually attributed to royalty as a symbol of power: the crown (stephanos, corona, and venets). This name derives from the very rite, which includes usage of crowns. During the Byzantine and post-Byzantine periods, the Church used the true crowns for marriage, and this continues to be the practice in Orthodox Churches in the Slavic countries.

The crown (a headgear that serves as a symbol of royalty) is the most obvious sign of the common sense and consequences of both rituals. Thus it appears essential for our study. Originally, the crown (corona $)^{10}$ was not a royal symbol but triumphal one. It is a circle made of flowers and leaves. In pagan times it was put on the head of the winner of competitions (both athletic and artistic). In Rome it was an attribute of the triumphatus, the person granted the triumph. The relation to victory, it is quite clear in this case, too, but we have to pay attention to the fact that the person granted by a triumph represented Iuppiter Optimus Maximus and wore some royal insignia. In a certain sense, the triumphatus has a strong at least symbolic relation to power. The crown as a symbol of triumph and victory is especially important for our study because it obviously participates in the scheme of representation of supernatural crowning of the victor: angels putting a wreath on the head of the winner/victor is a pagan invention that passed later to the ruler's investiture symbols in Byzantium and other countries ${ }^{11}$. Apart from being a triumphal symbol as a prize for a victory, the crown is a festal one too,

${ }^{10} \mathrm{CH}$. WALter, The Iconographical Sources for the Coronation of Milutin and Simonida at Gračanica, [in:] Византијска уметност почетком XIV века. Научни скуп у Грачаници, еd. С. Петковит, Београд 1978, p. 186.

${ }^{11}$ Ibidem, p. 190sqq. 
and as such was worn during different ceremonies, especially related to marriage and funeral rites. I do not think, however, that the crowns at Christian nuptials derive directly from the pagan festal practice: the easiest way to explain them is to pursue the festal/triumphal direction, which is, however, strongly related to the idea of power.

The diadem ${ }^{12}$ is a different symbol that finally was associated with the crown. It is a band decorated with pearls that sometimes has a big jewel in front. It was always a sign of royalty and power. As such it remained untypical for the Romans and was associated habitually with the Oriental and Hellenistic monarchies. Emperors wore crowns as symbols of victory and gave crowns to winners of different competitions, especially in the Hippodrome, but its relation to power was quite theoretical and mediated. In the later period we find some combination of crown and diadem in order to arrive at a headgear called crown, which represented the victor as well as the ruler in the Middle Ages. This innovation began with the monarchization of imperial power in the late third century and crystallized in the time of Constantine and his successors ${ }^{13}$. Another Constantinian innovation was the idea of God crowning the emperor with a wreath/diadem as a symbol of the divine origin of his power. The civic ritual of imperial investiture remained fundamental and lasted practically up to the end of the Empire in the mid- $15^{\text {th }}$ century, but the new Christian conception led gradually to the creation of an ecclesiastical rite that began in the fifth century and gained more and more at least moral importance. The practice that was introduced by Constantine is especially significant, because this emperor is the symbol and incarnation of the Christian ruler's idea, and this is why every reference to him can be seen as setting a standard for other holders of power. This concerns the emperor's headgear as well, thanks to the legend, told by Constantine Porphyrogenitus in De administrando imperio, revealing that the diadems and imperial robes were not made by men but sent by God to Constantine the Great as signs that God had granted him supreme power on earth ${ }^{14}$. The use of Psalm 20/21 in the coronation rite is extremely important, because it creates the link between the motif of power and the motif of victory, which together are related to God's intervention, help, choice and justice.

Thus the emperor became God's chosen and champion - therefore he was crowned by God - but he was not the only one. The martyrs and certain other Christian saints are usually represented with crowns. This headgear is given by Lord Jesus Christ to the bearers of the supreme virtues in some representations of the Celestial Ladder of John Climacus ${ }^{15}$. The just people have their crowns in the

\footnotetext{
${ }^{12}$ Ibidem, p. 186.

${ }^{13} \mathrm{Ibidem}$, p. 187, see also plate $1 \mathrm{c}$.

${ }^{14}$ Constantine Porphyrogenitus, De administrando imperio, ed. G. Moravcsik, trans. R.J.H. JenKINs, Budapest 1949, p. 66-67.

${ }^{15}$ J.R. MARTin, The Illustrations of the Heavenly Ladder of John Climacus, Princeton 1954, p. 16sqq. See the expression: The monk who is poor is lord of the world - Scala paradisi, [in:] PG, vol. LXXXVIII, col. 928.
} 
Heavens because of their being Christian champions. The use of the expression athlete of faith is common in the Early Christian as well as in some mediaeval writings. Exactly that sense justifies the use of crowns for martyrs too. The martyrs are pure victors and bearers of heavenly power in order to be propagators of the faith: they vanquish the enemies of God in a holy struggle for faith and Salvation by their martyrdom and that is why are able to become witnesses (the original sense of the word martyr) and thus propagate faith in God and squash Evil.

The crown used in the marriage rite has the same victorious meaning. In Ancient Greece, different types of wreaths and garlands were used in the marriage rites, but they were mostly festive symbols of a sort of Bacchanalia, which provoked a negative attitude toward nuptial crowns in some Christian authors ${ }^{16}$. Despite these commentaries, the Early Church probably used crowns, and this practice is confirmed by several authors from the fourth century onward ${ }^{17}$. We have such references in the works of St Gregory Nazianzen ${ }^{18}$, John Chrysostom ${ }^{19}$, the Pope Nicholas It in his Responsa ad consulta Bulgarorum ${ }^{20}$, in a Fifth century SyroRoman Lawcode $^{21}$, Theophylact Simocatta ${ }^{22}$ and so forth. Following the data from the Euchologia, the imposition of crowns by the officiating priest became regular from the tenth century onward ${ }^{23}$. It should be stressed that the period coincides with the controversy in Byzantium concerning the fourth marriage of Emperor Leo VI the Wise, the resolution of which led to the definitive clarification and stabilization of the ecclesiastical rite as a necessary juridical act for the creation of matrimonial relations, which was enacted by the same emperor's Novella $89^{24}$.

Nuptial crowns entered not only accounts and interpretations of the rite, but also its representations. They are quite typical for images of royal/imperial weddings, but in these cases we should bear in mind a possible influence from the

\footnotetext{
${ }^{16}$ CH. WALTER, Marriage Crowns in Byzantine Iconography, Зог 10, 1979, p. 8.

${ }^{17}$ Ibidem, p. 8sqq.

${ }^{18}$ Gregory of Nazianzus, Letter 231 - L. Anné, Les rites des fiançailles et la donation pour cause de mariage sous les Bas-Empire, Louvain 1941, p. 156.

${ }^{19}$ Joannis Chrysostomi, Archiepiscopi Constantinopolitani, Homiliae XVIII in Epistolam primam ad Timotheum. In Epistola I ad Timotheum caput II Homilia IX, [in:] PG, vol. LXII, col. 546.

${ }^{20}$ Responsa Nicolai PP, № 3: Responsa Nicolai Papae I. ad consulta Bulgarorum anno 866, ed. D. Dechev, Sofia 1922 [= УБ, 16], p. 13.

${ }^{21}$ K.G. BRuns, E. SACHAU, Syrisch-Römisches Rechtsbuch aus dem fünften Jahrhundert, Leipzig 1880, p. 23-27, 52sqq, 94, 128; H.J. WolfF, Witten and Unwritten Marriages in Hellenistic and Postclassical Law, Haverford 1939, p. 83sqq.

${ }^{22}$ Thophylacti Simocattae Historiae, ed. C. DE Boor, Lipsiae 1887, p. 57.

${ }^{23}$ А. Дмитриевский, Описание литургических рукописей, хранящихся в библиотеках Православного Востока, вып. II, Euchologia, Киев 1901, p. 4 (Sinait. 957, f. 22v), p. 30 (Sinait. 958, f. 78v); P. Trempelas, Mikron Euchologion, I, Athens 1950, p. 23sqq, 55sqq; J. Zhishman, Das Eherecht der orientalischen Kirche, Vienna 1864, p. 156-160.

${ }^{24}$ P. L'Huillier, Novella 89 of Leo VI the Wise on Marriage: Theoretical and Practical Impact, GOTR 32, 1987, p. 153-162.
} 
imposing presence of royalty; we shall comment on this later. We should emphasize certain representations of the couple of Cana of Galilee wearing crowns. We have at least four of them: Manuscript Iviron 5, f. 363v; Vienna, Library of Mechitharist Congregation, cod. 242, f. 191v; the mural painting in St Nicholas church, Ljuboten (Macedonia); the mural painting in St Nicholas Orphanus church in Thessalonica ${ }^{25}$. The representation of the couple resembles an imperial one, and not only because of the crowns but because of the complete iconographical scheme. Thus we can say that they bear their royal/imperial features only because they are on their nuptial feast, not even during the divine office but around the table. The suggestion is quite obvious, but it needs to be clarified in its deep sense.

Let us see what the meaning is of the crown of the martyrs, ascetics or spouses in the Early Church, and try to answer the question of its relation to the royal coronation, if any. Several citations lead to the conclusion that originally the marriage crown was perceived as a sign of purity and virginity. In his Homily 9 on I Timothy 2, cited above, John Chrysostom asserts that the crown is a prize for the triumph of virginity over the carnal temptations of the world ${ }^{26}$. The $11^{\text {th }}$-century canonist Nicetas of Thessalonica maintains that crowns should not be used during the nuptial rite in the case of second marriages, because it is a sign of virginity that ought to be absent in such a case ${ }^{27}$. The already mentioned Syro-Roman Lawcode calls the wreath the glorious crown of virginity. There are many cases that could confirm this point, but it is necessary to define its sense and to answer exactly why this meaning is given to the crown. We have already suggested that it has a similar or identical sense as in other cases ${ }^{28}$. Even taken as a symbol of virginity, it is directly related to the crown of virtues, given to the monks and martyrs by the Celestial King for having resisted torture or the temptations of the world, as already mentioned. Keeping one's virginity until marriage is to keep Christian virtue and to defeat Evil in the universal collision aiming toward the Salvation of Humankind.

Even if virginity is related to the universal victory over the hereditary Foe of mankind, I do not believe that this is the general, the most important, most significant essence of nuptial crowns. They are a part of a complex that is strongly related to the conception of power in several directions, as I shall try to examine here below. In the paired concepts of virginity-victory, I think the second is more important, while the first part is a way to confirm the victorious character of matrimony, which binds it to royalty. The first victim for the faith is the protomartyr Stephen, whose very name means crown. Thus we find instituted

\footnotetext{
${ }^{25}$ Ch. Walter, Marriage Crowns..., p. 5sqq. Cf. also note 39 on p. 15.

${ }^{26}$ Joannes Chrysostomos, Homiliae XVIII..., col. 546.

27 А. ПАвлов, Сборник неизданных памятников византийского иерковного права, Санкт-Петербург 1898, p. 30.

${ }^{28}$ Ch. WAlter, Marriage Crowns..., p. 8.
} 
a tradition that represents martyrs with crowns. This is the reason several references to holy martyrs and especially to the Holy Forty Martyrs of Sebastia are included in the nuptial divine service ${ }^{29}$. In the nuptial blessing prayers, the couple is related to the Forty Martyrs exactly because they receive crowns from Heaven. There is no need to underline that all the martyrs are not only witnesses of the faith but also imagines Domini, because Lord Jesus Christ in His Sacrifice is the First victim and archetype of all martyrs. Even more, He is victorious too because just through His Sacrifice and Passion, He vanquishes Death in the Universe forever. In His person we find the most brilliant, most obvious and most eloquent model that justifies the unity between Martyrdom, Victory and Royalty.

\section{Images and Archetypes}

The connection between Matrimony and Royalty could be articulated and proved by use of certain scriptural and other images and archetypes as well. We can find them in the liturgical texts, in certain representations and in a variety of ritual practices. Bearing in mind the normative character of the Old and New Testament readings during the divine offices for both rites, it is reasonable to pay particular attention to them and their connotation.

The nuptial service includes the chanting of some texts from Holy Scripture that could be specified as royal. For example, the verse, adopted from Psalm 8, 6 and framed in the imperative and in plural: Crown them with glory and honour. The priest chants it after the placing of the crowns on the heads of the couple. Psalm 8 is a typical royal psalm that combines the motif of victory over enemies with the motif of the chosen and crowned king. The use of this psalm is a clear reference to the similar character of both the nuptial office and the royal coronation. We should stress that in some cases the text of Psalm 8 is cited in its entirety during the divine service of marriage ${ }^{30}$.

Before the reading of the Epistle to the Ephesians and of the Gospel (Io 2, 1-11, Marriage in Cana of Galilee), the nuptial service includes a prokeimenon (chanting of psalm verses) from the royal Psalm 21/22, 4-5, changing the person from singular (for the King) to plural (for the couple): Thou set a crown of pure gold upon their heads. They asked life from Thee, and Thou gave it to them - Length of days forever and ever. Before the very coronation of the couple this - I repeat - typically royal Psalm is cited entirely (Ps 21/22, 1): The king shall joy in thy strength, O LORD; and in thy salvation how greatly shall he rejoice! etc.). It is also used in the coronation

${ }^{29}$ C. Pitsakis, Un thème marginal du culte de Saint Constantin dans l'Eglise d'Orient: Saints Constantin et Hélène protecteurs de la famille, Diritto @ Storia, № 2 Marzo, 2002 - Memorie, http://www. dirittoestoria.it/memorie2/Testi\%20delle\%20Comunicazioni/Pitsakis-marginal.htm [ 9 X 2013].

${ }^{30}$ L. cit. 
rite in the form Thou settest a crown of precious jewels upon his heads. He asked life from Thee, and Thou gave it to him - Length of days forever and ever ${ }^{31}$.

We see therefore the creation of an almost identical image of the participants in both rites de passage and it is confirmed by certain other practices as well. One of these is the nuptial rite of the so-called Bridegroom's sword. This ritual is very old, and it is testified to as such in certain manuscripts, but after the $19^{\text {th }}$ century it is very restricted in its area of application ${ }^{32}$. The description of the custom relates that the priest girded and armed the bridegroom with a sword and cited another royal psalm - 44/45. This old ritual was in practice in the Pontic (Black Sea) Greek Orthodox milieu until the first half of the $20^{\text {th }}$ century, and disappeared with the disintegration of these communities ${ }^{33}$. Our data about the application of the rite are mostly provincial and not directly associated with the imperial power in Constantinople, but obviously they created a royal image of the bridegroom and strengthened the relation between marriage and enthronement inauguration practice in Byzantium and the neighboring countries. This image does not only derive from the sword as a ruler's attribute, which underlines the military character of the winner and defender of the faith, assigned to the royalty. The latter is also confirmed by the contents of the text of the cited psalm, which is quite eloquent.

The Psalter is a royal book and certainly a part of the royal ideology for Hebrews and Christians. This is due mostly to the sense and the contents of the psalms, but also to their authorship, as they are attributed to King and Prophet David, whose image is certainly a royal paradigm par excellence. That is why the use of his person and of his texts for marriage is quite eloquent as to its conceptualization. Such a case offers the use of narrations or images of the nuptial/coronation of King and Prophet David with Michal, King Saul's daughter. They are the most frequently represented Old Testament couple in Christian art ${ }^{34}$. Bearing in mind the importance of the figure of King David for royal ideology, we are utterly justified in seeing in these representations a combination of the acquisition of nuptial wreaths and a royal coronation. We should stress that in all these cases we find not only the coronation as nuptial rite but also some other marriage gestures, such as dextrarum iunctio (a typical passage rite of relation to which we shall pay attention a bit later). In an illuminated copy of the Book of Kings from the Vatican Library (Vat. graec., 333, f. 24v), King Saul, on a throne, has in his arms both David and Michal ${ }^{35}$. This composition could be perceived as matrimony through royalty. Representations of the crowning of David and Michal - either nuptial or royal - are found in the illuminated Psalter from Vatican Library (Vat. graec. 752). The scene is represented

${ }^{31}$ I. Biliarsky, Le rite du couronnement des tsars dans les pays slaves et promotion d'autres 'axiai', OCP 59.1, 1993, p. 103-104, 1. 29-31.

${ }^{32}$ C. Pitsakis, Un thème marginal...

${ }^{33}$ L. cit.

${ }^{34}$ Ch. Walter, Marriage Crowns..., p. 4sqq.

${ }^{35}$ J. Lassus, L'illustration du Livre des Rois, Paris 1973, p. 54. 
three times in the manuscript that contains two cycles of David's life ${ }^{36}$. In the first of these cycles (f. 2), Saul crowns David and Michal and an inscription announces that the king of the People of Israel confers royalty upon them. The next two scenes convey the Psalm 151: one represents David alone, without Michal, crowned by Saul as co-ruler, and in the other Saul crowns David and Michal, which probably refers to the first Book of Samuel 18, 27. This verse is clearly and concurrently royal, victorious and related to matrimony, because King Saul gives his daughter Michal to David because he has destroyed the Philistines.

As was already stated, the theme of victory strongly relates matrimony to royalty. The bridegroom's sword is a suggestion of war and one of the typical royal images is that of a glorious victor. In the traditional, primarily folkloric culture, weddings are often related to war. This is the main topic of an attractive and stimulating book by Ivan Venedikov ${ }^{37}$, published more than quarter of century ago, that collected massive folkloric material but suffered - unfortunately - from all the ideological patterns of that time. To dismiss them is not amongst our goals, and I shall comment only some rational points that could be found in the Venedikov's study. First of all, we should stress the military character of the traditional Balkan (and not only Balkan) wedding ${ }^{38}$. This is obvious and quite well documented: the wedding procession of the bridegroom's family is organized and conceived as a martial campaign: it is equestrian, they have their banner, their commanders; the bride's home is like a fortress (or a fortified city) and the people of her family are its defenders; the bridegroom has to destroy the gates, to fight the bride's brothers and to conquer his future wife. We can find several explanations of these events but the most important is the victorious character of the marriage. This character is confirmed by certain archetypes in the folkloric texts. Here I would like to cite the narrative about the wedding of forty princes to forty brides who are king's daughters $^{39}$. We cannot avoid in this case referencing the Holy Forty Martyrs of Sebastia, who - as typical crowned martyrs - are well represented in the ecclesiastical wedding office.

There are also two more elements that link the traditional wedding to the ruler's ideology, and especially to the imperial veneration of St Constantine. First, there are certain motifs of the solar veneration that could be detected in the traditional marriage feast. These are quite well represented in the folkloric texts, and Ivan

\footnotetext{
${ }^{36}$ E. DE WALD, The Illustrations in the Manuscripts of the Septuagint III, Psalms and Odes 2, Vaticanus graecus 752, Princeton 1942, p. 4. 457.

${ }^{37}$ И. ВенЕдиков, Златният стожер на прабългарите, София 1987.

${ }^{38}$ The first part of the book is generally dedicated to this topic: Ив. Венедиков, Златният стожер..., p. 9-60 and sqq.

${ }^{39}$ А.П. МАртинов, Народнописни материали от Граово, СНУНК 49, 1958, р. 354, № 7; И. ДжуРенов, Народна проза от Пазарджишко, СНУНК 56, 1980, p. 132, № 78; Л. ДАСКАЛОвА-ПеРКОвСКА, Д. ДобРевА, Й. КоцевА, Е. МицЕВА, Български фолклорни приказки. Каталог, София 1994, p. 104-105, № 302A.
} 
Venedikov paid special attention to them ${ }^{40}$. This is the whole cycle of the marriage of the Sun we find in the Bulgarian folkloric songs and tales. The late scholar is inclined to see here an influence of the veneration of the Sun in the military circles in Late Antiquity, which passed into Bulgarian popular tradition in the $19^{\text {th }}$ and $20^{\text {th }}$ centuries. This is not impossible, but even in order to enter into details, we should identify in these remains mostly the veneration of the Sol invictus, then a local Thracian tradition. This imperial Roman pagan cult had a significant impact, especially in the Balkans in the Greek and Bulgarian milieux. I mean the Anastenaria tradition, as still exists in the mountainous region of Strandja, divided by the border between Bulgaria and Turkey next to the Black Sea littoral. It is not the subject of this research and I shall limit myself only to emphasizing that it takes place on the feast day of Sts Constantine and Helena and its very specific rite includes blood sacrifices and dancing on the blaze. The veneration of the holy emperor and his mother forms by definition a complex together with the veneration of the Holy Cross - a clear victorious symbol in Eastern Christianity. The connection of Anastenaria to Roman imperial veneration of Sol invictus is quite well studied, and the presence of the Sun, his wedding and his implications in marriage relations with humans give us an important opportunity to perceive a new interrelation between matrimony and power/royalty. As for the fire dancing tradition in Strandja, it is enough to say that one of the arguments for connecting it to imperial Solar veneration is precisely the use of the image of St Constantine.

The first Roman Christian emperor is surely an image of the pious and victorious ruler in Eastern Christianity, but additionally he is strongly represented during the marriage ceremony both in ecclesiastical and in folkloric practices. In Bulgarian folklore, there are (were) cases, when the husband had the ritual name of Constantine during the day of the wedding and especially during the rite itself, which presented him in a new quality, a new man who was not only husband but also a royal person ${ }^{41}$. The very act of marriage was called to go to Tsarigrad (Constantinople), which should signify to wed. Constantinople, the New Rome, is undoubtedly an imperial/royal space and paradigm. As a holy emperor (one of the few in Byzantium), Constantine is the archetype and model for Orthodox rulers. His person and its use in the marriage rituals, to be sure, strongly associates matrimony and royalty in Eastern Christianity. Maybe the clearest expression of the relation between marriage and royal coronation is found in the Armenian Church, where the bridegroom is called takhavor (King) not only on the day of the

\footnotetext{
${ }^{40}$ И. Венедиков, Златният стожер..., p. 266sqq, 387sqq.

${ }^{41}$ It is to note that new man may redirect toward the royal ideology as the ruler is usually perceived as imago Christi. Lord Jesus Christ is, sure, a new man being a New Adam. All of these is related to the idea of renovation that is essential for the imperial ideology - P.J. AlexAnder, Strength of the Empire and Capital as Seen through Byzantine Eyes, S 37, 1962, p. 351-354; I. Biliarsky, The Tale of the Prophet Isaiah. The Destiny and Meanings of an Apocryphal Text, Leiden 2013, p. 163sqq.
} 
wedding but also eight days after ${ }^{42}$. In Greek popular songs, the spouses are called basileus and basilissa.

Constantine's archetypal figure is even most important in our case because of his obvious association with Victory through the veneration of the Holy Cross. It became the Labarum of the Christian Roman army and the divine sign of triumph over the enemies of God, because Constantine saw it on the eve of the battle at Milvian Bridge. The Holy Cross is related to the holy emperor, because the wood of the Lord's Passion was found by his saintly mother in Jerusalem. The importance of the Constantinian model for the imperial ideology is beyond doubt and I do not intend to discuss and prove it here. It is important, however, that the veneration of Sts Constantine and Helena is connected to matrimony and they are perceived as celestial protectors of the family. Constantinos Pitsakis offered a special study on the topic and justifiably labeled that part of the holy emperors' veneration marginal ${ }^{43}$, but it is of special importance for this present research and I shall discuss it concisely.

Sts Constantine and Helena are (were) venerated as protectors of the family and especially by couples during weddings that occurred in Greece, Bulgaria, Armenia and so forth. We find this not only in folklore but also in high culture. The holy emperor and his mother are well represented in the nuptial ecclesiastical service as well. St Helena is evoked several times in the text of the ordo. Both of them are cited openly as divine protectors of the family in the apolysis (the final benediction) of the nuptial office, together with the Mother of God, the Holy Apostles and a few other saints.

As the nuptial service does not include its own liturgical hymns, in Byzantium the Church used in marriage the kontakion and apolytikion for the feast of Sts Constantine and Helena. St Constantine and his mother have an important place in the ecclesiastical calendar with their holiday (May 21), which is the focus of celebrations during the imperial Constantinopolitan month of May, together with the City's birthday - May $11^{\text {th }}$. This entire complex is strongly related to Christian imperial political ideology, to the salvation mission of the Empire and its role in universal history. That is why its connection to the ritual practice of marriage is especially important for the interpretation of the latter in the context of royalty or/and vice versa. The very texts of the kontakion and apolytikion confirm it ${ }^{44}$.

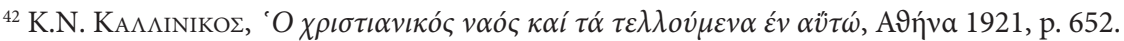

${ }^{43}$ C. Pitsakis, Un thème marginal...

${ }^{44}$ See the texts and commentaries in the article of C. PITSAKIs, Un thème marginal...: Apolytikion: Having seen in the Heaven the sigh of Thy Cross and having received, as Paul did, an appeal that was not of human origin, the Emperor became Thy apostle, O Lord, and entrusted the imperial City in Thy hands. Save it ever in peace by the intercession of Theotokos. And have pity to us (or: Thou, the only philanthropist). Kontakion: Today Constantine with his mother reveal to us the Cross, the most venerable Wood, which is the shame of Jews but for the faithful rulers it is their weapon versus the foes, because it revealed for us a great miracle, horrifying in the wars.
} 
In these texts we find all the important imperial themes, related to the political ideology of the Christian Eastern Roman Empire: a pious ruler, humble to God; a victorious emperor, who conquers his enemies by the strength of the Lord's Cross; the capital City (theosôstè), divinely saved by the intercession of the Mother of God, which is the center and eye of the Christian world; the isapostolos (equal to the apostles) emperor, propagator and defender of faith. All of these texts, which are chanted at the nuptial service, witness to its imperial understanding and the interrelation and interdependence between matrimony and power.

\section{Dextrarum iunctio and the Unity}

At the end of this survey of the common features of royalty and matrimony, I would like to add one more ritual practice that took place with both of them. It is not related to any insignia of power but is quite compelling in regards to the instituted relations. This is so-called dextrarum iunctio or right-handholding, righthandshake between the spouses of the family couple and the persons in power, respectively ${ }^{45}$. Maybe this practice originates in marriage ${ }^{46}$, but in the imperial Roman period it passed to military representations and finally to those of power. We find many such representations on coins, sculptures and so on. All these power and military cases are certainly interrelated, and the sense of the handholding is the same: the triumph of the peace of Pax Romana. This sense covers the essence of Roman political ideology, and was candidly expressed by inscriptions accompanying certain representations of the imperial handshake: Pax et libertas; Consensus exercitus; Concordia Augustorum; Pietas saeculi; Concordia/Fides/Pietas mutua Augustorum, etc. ${ }^{47}$ So we see that the gesture of holding hands is an expression of the mutual consensus and fidelity that is at the basis of peace as a fundamental concept of Roman political doctrine. It is central not only for the state and public society but, to be sure, for the family as micro-society and micro-cosmos as well. We saw that it passed from marriage to the political sphere, but the sense is equally shared between both. Maybe this is the reason why the most expressive examples of dextrarum iunctio reunite familial and political concepts: the handholding of the imperial couples and especially that of Caracalla and Plautilla, with the inscription Concordiae aeternae, Concordia felix, propago imperi ${ }^{48}$. It stresses the unity of family and the unity of power, the extension of the family harmony to agreement, unity, order and peace in the Empire. This is surely an expression

\footnotetext{
${ }^{45}$ I would like to recommend the interesting study of Father Christopher Walter on this topic: CH. WALter, The 'dextrarum junctio' of Lepcis Magna in Relationship to the Iconography of Marriage, AAf 14, 1979, p. 271-283.

${ }^{46}$ L. Reekmans, La 'dextrarum junctio' dans l'iconographie romaine et paléochrétienne, BIHB 31, 1958, p. 23-95.

${ }^{47}$ See the numerous citations in CH. WALter, The 'dextrarum junctio'..., p. 273-275sqq.

${ }^{48}$ Ibidem, p. 275.
} 
of a pagan concept of universal harmony, but the notion of peace and unity is not at all unfamiliar to Christianity.

The practice of dextrarum iunctio also entered Christian nuptial practice, but it never became a constitutive element of ecclesiastical marriage. It always remained an expression of mutual consent and of reciprocal fidelity ${ }^{49}$. As such, and together with the jugum and nuptial crowns, it is a sign of the creation of matrimonial unity and solidarity. This unity is already unity in Christ. Symeon of Thessalonica wrote that the priest unites the right hands of the couple, aiming to confirm and demonstrate that they are already united in God and they become one entity in $\mathrm{Him}^{50}$. Meanwhile, the handholding is not so typical for Byzantine imperial representations of power, because that power belongs to and derives from God, and its civic republican sense of harmony and accordance remains at a secondary level. We do find it, however, at imperial weddings, which certainly combine the idea of matrimony and that of authority. Here we have to return again to the biblical archetypes of both power and marriage. Old Testament patriarchs are without any doubt figures of power of the royal type. As ancestors of the Chosen People, they unite the image of king and leader with that of father. This is why it is important to note the cases of representation of dextrarum iunctio in them. Father Christopher Walter signals several such cases ${ }^{51}$ : Moses and Sephora, Jacob and Rachel, etc.

It is especially important to stress one clearly archetypal case that we have already mentioned: King and Prophet David and Michal. They are represented as right-handholding on one of the Cyprus plates with David's life cycle, dated to the period of Heraclius ${ }^{52}$. The young couple is represented against the background of an architectural composition: from both sides they are surrounded by two musicians playing flutes; David and Michal hold hands, linked in-between by a figure that should be King Saul. For me, there is no doubt that the representation is both royal and nuptial. King David is the very image of pious kingship, chosen by God, humble and repentant. King Saul is an image of royalty as well, and despite the fact that he is not so pious and humble, he has the priority of being the first chosen king of the Chosen People. Michal is the connection between them. The wedding of David and Michal is certainly related to the royalty of Jesse's son. So we see a representation of both royalty and matrimony united by a gesture of consent, Concordia and peace. They expose an ideal, being the focal point of all imagery of harmony and solidarity.

\footnotetext{
${ }^{49}$ Ibidem, p. 277sqq.

${ }^{50}$ Symeonis Thessalonicensis, Archiepiscopi, De honesto et legitimo conjugio, [in:] PG, vol. CLV, col. 509; С H. Walter, The 'dextrarum junctio'..., p. 277.

${ }^{51} \mathrm{CH}$. WAlter, The 'dextrarum junctio'..., p. 277-282.

${ }^{52}$ Wealth of the Roman World, AD 300-700. Exhibition catalogue, ed. J.P.C. Kent, K.S. PAInTER, London 1977, p. 103 № 180; СH. WALter, The 'dextrarum junctio’..., p. 280-281.
} 


\section{Character of the Relation. Conclusion}

I think that the corresponding character of the rites and of the integral nature of the interconnection between King and Kingdom and between both spouses of the marriage couple is out of doubt, but it remains to specify its essence. This specification could help us to distinguish the role of the figure of the woman as legitimating power in the case of royalty in connection with its correspondence to marriage. In order to arrive at a conclusion, I would going back to our thesis that both initiating rituals are rites de passage of relation, so as to assure a new status of relation amongst the participants.

We see then that the legitimation and confirmation of the kingship in some pagan cultures passed through a hierogamy, conceived as a unity with the universal harmony in the image of a chthonic goddess. This unity is expressed by a (pagan sacred) marriage that usually includes sexual intercourse between the King and the deity as well.

In the monotheistic milieus, we find some formally similar traits that bear a fundamentally quite different sense. Christian marriage is a relation between man and woman, instituted by God after the model of the relation between Lord Jesus Christ and His Church. The latter was the subject of many interpretations, but I would like to pay attention especially to those that treat the Song of Songs that is Solomon's (or Canticles) and the episode of the meeting of King and Prophet Solomon with the Queen of Sheba, presented in the Bible but also in the Quran and in the Ethiopian book of Kebra Nagast ${ }^{53}$. Viewed through a Christian lens, both of these accounts (i.e. that from the Song of Songs and that from Kebra Nagast) present the relations between the bride and the bridegroom under the archetypal model of the relation of Jesus Christ to His Church, He being a priest and king of the order of Melchisedek (Ps 109/110, 4; Heb 7, 14-17). Melchisedek, the King of Salem, is a veterotestamentarian paradigm for the priesthood but also for the royalty. Both cases cited above (the Canticles and the Queen of Sheba's story) are put together in the commentary of Origen on the book of the Song of Songs, where the bride and bridegroom are interpreted as the same image of Jesus Christ and His Church, as in the case of King Solomon and the Queen of Sheba ${ }^{54}$. It is to be underscored that the image of Melchisedek in Christian theology is exactly a new type of king that corresponds to the incarnated Logos but not to the Davidic royalty. Thus, the model of relation becomes more universal and is not restricted

\footnotetext{
${ }^{53}$ Kebra Nagast. Die Herrlichkeit der Könige (Nach den Handschriften in Berlin, London, Oxford und Paris), ed. C. Bezold, München 1905; E.A. Wallis Budge, The Queen of Sheba and her Only Son Menyelek (I), Oxford-London 1932; G. Colin, La gloire des rois (Kebra Nagast). Epopée nationale de l'Ethiopie, Genève 2002 [= COr, 23], p. 118.

${ }^{54}$ Origène, Commentaire sur le Cantique des cantiques, I, Texte de la version latine de Rufin, intr., trans. et notes L. BrÉSARD, S.J.H. Crouzel, Paris 1991 [= SC, 375], p. 274-293.
} 
to the Hebrews as the Chosen People ${ }^{55}$. Lord Jesus Christ (and Melchisedek as His prefiguration in the Old Testament) is Priest and King, but in relation to the Church (the faithful people) as to His body, He is ever in royal quality. In the scriptural, theological and poetic texts, the Bride (and so the Church, as seen in the Song of Songs) is called only queen.

This concept passed from theology to liturgical practice and finally to the rituals of power. Ritual is not only the decoration of power, its ornament or propaganda. It is an integral part of the phenomenon of authority, one of the ways for it to be legitimized and to be exercised. The notion of union is crucial both for marriage and for coronation. The original connection of the nuptial service to the Eucharistic liturgy is strong argument is this sense because the marriage becomes relation to the Communion as a supreme union. The parallelism between both rites supposes the special relation of the king to power or to the state (conceived as the unity of people and country), which is usually represented by the model of the relations between husband and wife as a general model of the integral relation in this world, having its archetype in the heavenly one. That is why the rite of passage to Kingship corresponds to that of marriage, instituted by Lord Jesus Christ under the model of His own relation to the Church. That is why both of them repeat more and more certain ritual gestures that confirm the unity, harmony, accord, consent and Concordia - all of them basic for relations of this type.

And in the very end, I shall cite my late friend Constantinos Pitsakis, who proposed a supplementary theological interpretation of matrimony as a source of power, taken from the Old Testament and especially from the Book of Genesis 1, 28:

\footnotetext{
And God blessed them (Adam and Eve), and God said unto them, 'Be fruitful, and multiply, and replenish the earth, and subdue it: and have dominion over the fish of the sea, and over the fowl of the air, and over every living thing that moveth upon the earth'.
}

We see that God gave power to Adam and Eve, the first couple. It should be stressed that Adam (as well as all the Old Testament patriarchs) is a royal image and paradigm. He is a prefiguration of Lord Jesus Christ, Who is called New Adam. The bridegroom takes on this quality during the nuptial and he obtains universal power exactly by entering the matrimonial relation because of the propagation, multiplication and recreation of Humankind, and thus represents an imitation, a mimesis and continuation of God's work. In order to be such, the bridegroom cannot be alone, because in order to obtain such a power, he needs his bride.

\footnotetext{
${ }^{55}$ Vide I. Biliarsky, The Birth of the Empire by the Divine Wisdom and the Ecumenical Church (Some Observations on the Ethiopian Book of Kebra Nagast), [in:] The Biblical Models of Power and Law/Les modèles bibliques $d u$ pouvoir et du droit, ed. I. Biliarsky, R.G. PăUn, Frankfurt am Main et al. 2008 [= RRei, 336], p. 23-43.
} 


\section{Bibliography}

\section{Sources}

Adventures of the Sons of Eochaid Mugmedon, [in:] Ancient Irish Tales, ed. T.P. Cross, C.H. SLover, London 1936, p. 508-513.

BRuns K.G., SACHAU E., Syrisch-Römisches Rechtsbuch aus dem fünften Jahrhundert, Leipzig 1880.

Colin G., La gloire des rois (Kebra Nagast). Epopée nationale de l'Ethiopie, Genève 2002 [= COr, 23].

Concil. Trident., canon I, Sess. XXIV, [in:] CONCILIUM TRIDENTINUM. Canones et Decreta, 1545-1563, p. 96 - http://www.documentacatholicaomnia.eu/04z/z_1545-1563_Concilium _Tridentinum_Canones_et_Decreta_\%28Altera_Lectio\%29_LT.pdf.html

Constantine Porphyrogenitus, De administrando imperio, ed. G. Moravcsik, trans. R.J.H. JenKINS, Budapest 1949.

Giraldus Cambrensis, The Topography of Ireland, trans. Th. Forester, ed. Th. Wright, Cambridge-Ontario 2000.

Gregory of Nazianzus, Letter 231, [in:] L. Anné, Les rites des fiançailles et la donation pour cause de mariage sous les Bas-Empire, Louvain 1941.

Joannis Chrysostomi, Archiepiscopi Constantinopolitani Homiliae XVIII in Epistolam primam ad Timotheum. In Epistola I ad Timotheum caput II Homilia IX, [in:] PG, vol. LXII, col. 543-548.

Kebra Nagast. Die Herrlichkeit der Könige (Nach den Handschriften in Berlin, London, Oxford und Paris), ed. C. Bezold, München 1905.

ORIGÈne, Commentaire sur le Cantique des cantiques, I, Texte de la version latine de Rufin, intr., trans. et notes L. BréSArd L., S.J.H. Crouzel, Paris 1991 [= SC, 375], p. 274-293.

Responsa Nicolai PP, No 3, Responsa Nicolai Papae I. ad consulta Bulgarorum anno 866, ed. D. Dechev, Sofia $1922[=$ УБ, 16].

Scala paradisi, [in:] PG, vol. LXXXVIII, col. 632-1164.

Symeonis Thessalonicensis, Archiepiscopi, De honesto et legitimo conjugio, [in:] PG, vol. CLV, col. 503-515.

Thophylacti Simocattae Historiae, ed. C. DE Boor, Lipsiae 1887.

ПАвлов А., Сборник неизданных памятников византийского иерковного права, Санкт-Петербург 1898.

\section{Secondary Literature}

Alexander P.J., Strength of the Empire and Capital as Seen through Byzantine Eyes, S 37, 1962, p. 351-354.

ANNÉ L., Les rites des fiançailles et la donation pour cause de mariage sous les Bas-Empire, Louvain 1941.

BILIARSKy I., Le rite du couronnement des tsars dans les pays slaves et promotion d'autres axiai, OCP 59.1, 1993, p. 91-139.Biliarsky I., The Birth of the Empire by the Divine Wisdom and the Ecumenical Church (Some Observations on the Ethiopian Book of Kebra Nagast), [in:] The Biblical Models of Power and Law/Les modèles bibliques du pouvoir et du droit, ed. I. BILIARsKY, R.G. PĂUn, Frankfurt am Main et al. 2008 [= RRei, 336], p. 23-43.

Biliarsky I., The Tale of the Prophet Isaiah. The Destiny and Meanings of an Apocryphal Text, Leiden 2013. 
Biliarsky I., Deux ensembles de rites de passage concernant la personne et la 'Res publica' : Baptême/Onction et Mariage/Couronnement, [in :] Personne et RES PUBLICA, éd. J. Bouineau, Paris 2008, p. 239-253.

Cannadine D., Introduction: divine rites of kings, [in:] Rituals of Royalty. Power and Ceremonial in Traditional Societies, ed. IDEM, S. PRICE, Cambridge 1987, p. 1-19.

van Gennep A., Les rites de passage, Paris 1909.

Herbert M., Goddess and King: The Sacred Marriage in Early Ireland, [in:] Women and Sovereignty, ed. L.O. Fradenburg, Edinburgh 1992 [= C.YTCS, 7], p. 264-275.

L'Huillier P., Novella 89 of Leo VI the Wise on Marriage: Theoretical and Practical Impact, GOTR 32, 1987, p. 153-162.

Lassus J., L'illustration du Livre des Rois, Paris 1973.

Martin J.R., The Illustrations of the Heavenly Ladder of John Climacus, Princeton 1954.

PITSAKIs C., Un thème marginal du culte de Saint Constantin dans l'Eglise d'Orient: Saints Constantin et Hélène protecteurs de la famille, "Diritto @ Storia” No 2 Marzo, 2002 - Memorie, http://www. dirittoestoria.it/memorie2/Testi\%20delle\%20Comunicazioni/Pitsakis-marginal.htm.

Reekmans L., La 'dextrarum junctio' dans l'iconographie romaine et paléochrétienne, BIHB 31, 1958, p. 23-95.

Trempelas P., Mikron Euchologion, vol. I, Athens 1950.

DE Wald E., The Illustrations in the Manuscripts of the Septuagint III, Psalms and Odes 2, Vaticanus graecus 752, Princeton 1942.

Wallis Budge E.A., The Queen of Sheba and her Only Son Menyelek (I), Oxford-London 1932.

Walter CH., Marriage Crowns in Byzantine Iconography, Зог 10, 1979.

WALter CH., The Dextrarum Junctio of Lepcis Magna in Relationship to the Iconography of Marriage, AAf 14,1979 , p. 271-283.

Walter CH., The Iconographical Sources for the Coronation of Milutin and Simonida at Gračanica, [in:] Византијска уметност почетком XIV века. Научни скуп у Грачаници, еd. С. Петковић, Београд 1978, p. 183-200.

Wealth of the Roman World, AD 300-700. Exhibition catalogue, ed. J.P.C. Kent, K.S. PAInTER, London 1977.

Wolff H.J., Witten and Unwritten Marriages in Hellenistic and Postclassical Law, Haverford 1939.

Zhishman J., Das Eherecht der orientalischen Kirche, Vienna 1864.

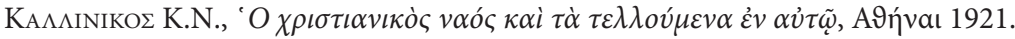

$* * *$

ВенЕдиков И., Златният стожер на прабългарите, София 1987.

ДАСКАЛОвА-ПЕРКОвСКА Л., ДОбРЕВА Д., КОЦЕвА Й., МИЦЕвА Е., БблгарсКИ фолклорни приказКИ. Каталог, София, 1994.

Джуренов И., Народна проза от Пазарджишко, СНУНК 56, 1980, p. 1-472.

Дмитриевский А., Описание титургических рукописей, хранящцихся в библиотеках Православного Востока, вып. II, Евхология, Киев 1901.

МАртинов А.П., Народнописни материали от Граово, СНУНК 49, 1958, p. 1-840. 


\begin{abstract}
This article is devoted to the question concerning the conceptualization of power and its religious basis in pre-modern societies, carried out through a study of the inauguration rituals - especially the marriage - that mark not only the instigation of the power of the ruler but also suggests its religious basis, conceptualization and justification. It is grounded on source material from Byzantium and its legacy in the countries of South-Eastern Europe and the Eastern Mediterranean. The analysis has shown the woman as legitimating power in the case of royalty in connection with its correspondence to marriage. The legitimation and confirmation of the kingship in some pagan cultures passed through a hierogamy, conceived as a unity with the universal harmony in the image of a chthonic goddess. From the Christian point of view the relations between the royal bride and the bridegroom was under the archetypal model of the relation of Jesus Christ to His Church. He (Christ and the christian ruler) became a priest and king of the order of Melchisedek. That is why the rite of passage to Kingship corresponds to that of marriage, instituted by Lord Jesus Christ under the model of His own relation to the Church.
\end{abstract}

Keywords: power conceptualization and legitimization, pre-modern societies, rite de passage, Christian marriage, Byzantine political and religious ideology, Orthodox liturgy and theology.

Ivan Biliarsky

Institute for Historical Studies

Bulgarian Academy of Sciences

52 Shipchenski Prohod Boulevard, ap. block 17

1113 Sofia, Bulgaria

ivan.biliarsky@gmail.com 